\title{
The Risks of Commercial Banks on Interest Rate Marketization
}

\author{
Yue Zhang \\ Economic and Management School of WuHan University, WuHan University, WuHan, China \\ Email address: \\ Andrew_zy@126.com

\section{To cite this article:} \\ Yue Zhang. The Risks of Commercial Banks on Interest Rate Marketization. International Journal of Economics, Finance and Management \\ Sciences. Vol. 4, No. 2, 2016, pp. 83-86. doi: 10.11648/j.ijefm.20160402.17
}

Received: February 25, 2016; Accepted: March 8, 2016; Published: March 21, 2016

\begin{abstract}
The interest rate of market reform and deepening of our country commercial bank stability and sustainable development of the important and far-reaching impact. Is the core of modern economy and financial interest rates, as the price of money, interest rate plays an important role in the allocation of resources. As the interest rate market advance, domestic commercial bank's overall risk level is lower than the optimal risk. In this paper, in combination with the practical situation of the market, on how the commercial Banks under the background of market-oriented interest rate risk prevention, risk aversion caused by excessive systemic risks are expounded.
\end{abstract}

Keywords: Interest Rates, Commercial Banks, Risk-Taking, Reform

\section{Introduction}

A significant reform in the field of finance in China is the interest rate reform in 1978, after that, until 1996 at an annual rate of the pace of the market began to move forward. Myrdal argues that interest rate marketization can help to increase the capital investment, promote the accumulation of capital. For a long time, he thought, all countries in implementing the strategy of financial repression, the factors of production can't release, and want to maintain long-term economic development, its core is to make full use of all factors of productions [1].

Of the 21 st century today, the interest rate of market reforms have after nearly 20 years, the current interest rate market reform has entered new sprint. What is undeniable is that the emergence of the commercial bank interest rates in the market for the development of commercial Banks has brought unprecedented opportunities for development, in addition, each commercial bank has the right to financial products pricing, the innovation of financial derivatives in the field of potential. Therefore, the development of commercial Banks and management of interest rate market brings a huge challenge. Is the core of modern economy and financial interest rates, as the price of money, interest rate plays an important role in the allocation of resources. As the interest rate market advance, domestic commercial bank's overall risk level is lower than the optimal risk [2].
In short interest rates change market is determined by supply and demand of money market interest rates, today, the market economy condition, the interest rate level will depend on the market. Although the monetary authorities to effectively control the interest rate, but the market main body to interest rates have the initiative. Based on this, the interest rate market is essential to the market positioning is, in fact, the interest rate control. At present, the main body of market competition conditions, insufficient market under the condition of the commercial Banks to resist the ability of the risk, so the interest rate market on the development of commercial Banks and more important impact on business. Moreover, in today's market conditions, interest rate fluctuation is bigger, and more frequent, commercial Banks in accordance with their own ability to fluctuations in interest rates and trends are difficult to accurately forecast, which to a certain extent, increase the difficulty that the accurate and rapid response [3]. When the lack of appropriate financial instruments to hedge interest rate risk, will further aggravate the financial risks of commercial Banks. In addition, the rate of frequent fluctuations in bond prices, thus, to a certain extent, increase the holding bonds the financial risks of commercial Banks. Rates of city commercial Banks with independent pricing power, it is the independent pricing power has also exacerbate the risk. Today, commercial bank competition is one of the fundamental tools of interest rates, easier for price 
competition between Banks for the customers, also effectively improve the price war, higher deposit rates, lower loan interest rates, which affect bank of traditional business income. In addition, the regulation does not reach the designated position, because of human relations in both advantages and disadvantages, the breeding ground for corruption certain financial, increase the risk of bank management. In addition, the interest rate market, looking for accurate measures to cope with the situation, be badly in need of a large number of professional technology and talent, and the interest rate operation itself, will create the risk that nots allow to ignore [4].

\section{The Interest Rate Market to the Risks of Commercial Banks}

\subsection{The Risk of Transition Period}

Interest rate market reforms appear relatively late in our country, the domestic commercial Banks are exposed to interest rates for the first time in the beginning of reform and opening up the market, because of the commercial bank itself is difficult to adapt to the change of market environment, so there is no together with the present situation of their own to take effective countermeasures. Based on this, in today's society, the interest rate is changed market eased regulation is bound to the development of our country commercial bank financial risk. Based on the interest rate control to the development demand of marketization of interest rate, have a certain financial risks and factors, commercial Banks can be a huge change development has experienced various risks under threat, can say it to a certain extent, affected the normal management and operation of commercial bank [5].

\subsection{The Gap Balance of Risk}

Interest rate of market in a certain impact on the domestic financial environment, for the development of commercial Banks, interest rates change market will inevitably result in changes of the structure of assets and liabilities. In addition, because is affected by the debt term and quantity, the income of commercial Banks will also because of the interest rate market accordingly due to the change. Our country commercial bank in debt for a long time, influenced by the number of a certain time limit and liabilities, the deposit and lending ratio imbalance, so to a certain extent can cause bank debt ratio is reduced, the commercial Banks in this short period of time to adapt to change, therefore, will produce risk gap accordingly. Harsh, because of the interest rate market in terms of the risks of commercial Banks by risk impact includes the option risk and risk of interest rate structure. The development of China's commercial Banks for interest rates in the market environment, assets, liabilities is in a state of relative changes, so important for commercial Banks to adjust and change. If a commercial bank itself is difficult to make sure that the deposit and lending interest rate fluctuations in the same direction and would reduce lending and deposit rates accordingly, but also effective to a certain extent reduce the commercial bank's net interest income, even if the short - and long-term lending and deposit rates lead to deposit payment rate, cause certain impact bank asset liability structure, commercial Banks in this case need to take the initiative to the influence of risk changes, thus causes deposit customer nominal interest rate changes, can effectively to a certain extent, timely adjust lending quotas [6].

\subsection{Liquidity Risk}

Interest rate is changed under the market commercial Banks will be allowed to use a more flexible and convenient tools and means to adjust the structure of debt, absorb deposit accordingly., to say the debt structure adjustment, absorb deposits can to a certain extent, improve the period of the structure of the assets and liabilities, complexity, it also lead to unstable balance sheet project. Based on the asset side, high yield, low liquidity proportion to rise. Commercial Banks to improve the asset returns, as far as possible to reduce capital levels, reduce revenue efficiency of capital utilization. Stability based on the liability side, the deposits of commercial Banks is likely to decline, and after the deposit interest rate floating, the difference between different bank rate will rise greatly, between various deposits, especially can accelerate the flow of savings Banks between frequency and increase the flow of the scale efficiency. In addition, the deposit in advance, such as mortgage prepayment of a frequency will be much higher than before, the emergence of this situation, increasing the vulnerability of commercial bank debt structure, lead to some commercial bank liquidity risk.

\subsection{The Risk of Option}

Optionality from bank assets and liabilities including off-balance sheet business is contained in the option. Options as a separate, in the court when trading activities and otc options can be implied in the standardization of other financial instruments. Such as bonds and deposit in advance, to repay the loan ahead of schedule, and so on. Generally speaking, the option and the option of the terms and conditions are caused by asymmetric bring some risk characteristics of payment to the seller. If interest rates change good for depositors and lenders, bank depositors can choose to reschedule, the borrower can arrange loans, and harmful to the bank.

According to related regulations, the customers of commercial Banks shall have the right to withdraw deposit, to repay the loan ahead of schedule, and after the interest rate adjustment, will appear a large number of withdrawals or payments in advance, so that China's commercial Banks are able to afford to optionality [7].

\section{The Present Situation of Chemical Market Interest Rates and Risk Bearing}

\subsection{Part of the Bank's Net Interest Rates}

The present situation of chemical market interest rates and risk bearing. 
In order to be able to accurately reflect the actual situation of our country commercial bank system, this paper selected the middle peasants labor built five rows with merchants, citic, societe generale three national commercial bank, bank of Beijing, nanjing bank two local city businesses as sample, select the data from 2008 to 2014. Through the national statistical yearbook, open Banks as well as the people's bank of China annual report data according to the data model for data collection. To facilitate the analysis and comparison, based on the model set, all data are reflected in the form of percentage data, ensure the comparability. Upon completion of the selection of data, we use relevant software operations on these data, in order to determine the influence of different factors for the size of the risk of interest rate liberalization [8].

Interest rates as the financial industry to capital-intensive industry, industry maintained a high level for a long time, the local commercial bank overall operating effect is good, this suggests that the newly established financial institutions in the internal management efficiency is more outstanding. State five line, agricultural bank management effect is poorer, this match their status in capital markets, to further improve operation effect.

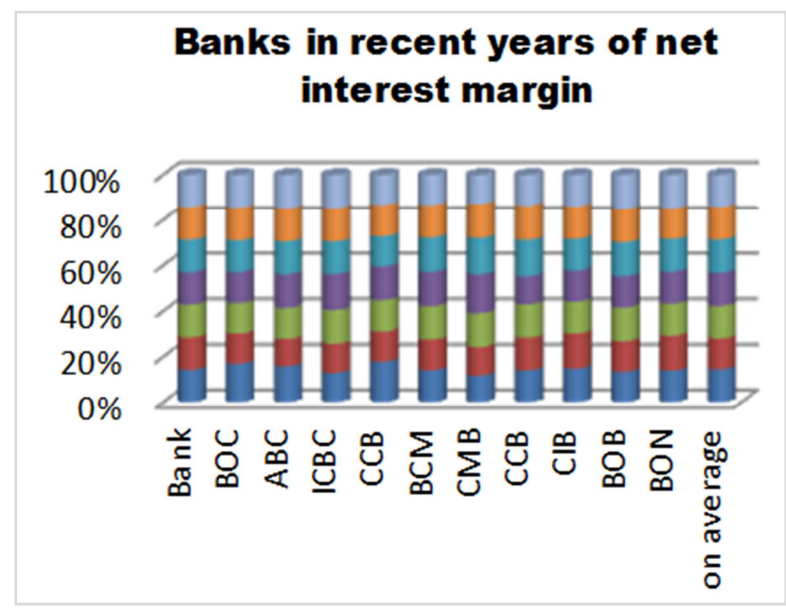

Figure 1. Banks in recent years net profit margin.

\subsection{Banks Non-performing Loan Yatio}

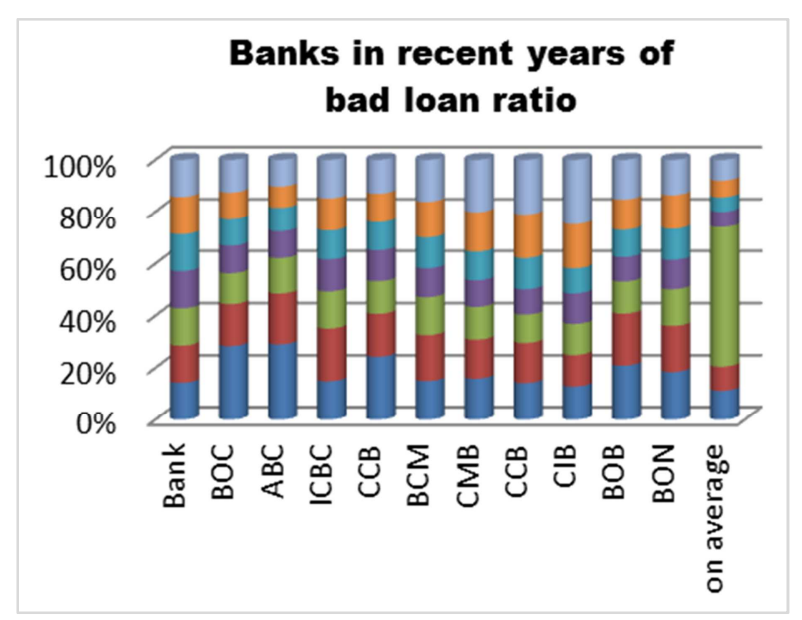

Figure 2. Banks in recent years of bad loan ratio.
Non-performing loan ratio is an important content of the commercial bank by market value, is one of a core factor to measure the quality of bank assets. Due to the high bank assets, such as bank of China, the total assets of more than ten trillion yuan, if the non-performing loan ratio of each growth of $1 \%$, will run off most of its profit, can lead to overall bank business get into trouble. From the point of data, joint-stock Banks and local commercial Banks non-performing loan ratio is much lower than the five big state-owned Banks non-performing loan ratio, this suggests that the local commercial Banks and joint-stock Banks is more excellent in terms of risk control. Need our attention is that, since 2014, the non-performing loans of commercial Banks is a larger increase [9].

\subsection{The Results and Discussion}

Through the analysis, the interest rate market in the process of advance, the bank didn't enlarge management risk, and reduce the risk of. The emergence of this phenomenon, because of the interest rate market advance, it makes commercial bank more understand management, and objectively to avoid the interest rate on a certain scale, the impact of the market. The non-performing loans of commercial Banks and business risk present certain positive correlation, it also suggests that the bank's non-performing loans is high, the higher the risk, to a certain extent, increasing the risk of commercial Banks.

Market-oriented interest rate reform is the need of the development of market economy, is one of the important steps we further deepening the reform of market system. From the point of the pace of reform, regulators are determined according to the market environment and orderly, after more than 20 years of time, finally completed the initial reform of the market. Commercial Banks in the process of market-oriented interest rate reform will face various possible risks, once these risk is beyond the scope of commercial bank itself can bear, would pose a risk to commercial bank system, which affect the whole macro environment. From the recent 20 years, global economic crisis is caused by the financial crisis, the financial industry are inherently creative impulse of genes, once excessive freedom, will accumulate a lot of risk.

As completed preliminary market-oriented interest rate reform, China's commercial Banks will face a new development environment, in the current macro-economic downward pressure increasing, under the condition of development of commercial Banks will face more severe challenges. Therefore, we must to highly the attention of the market risk of interest rate changes, the market participation main body to actively cope with the possible problems. The risk of commercial Banks to change the traditional control system, and adjust the risk awareness, strengthen the prediction of risk of interest rate changes, the use of modern way of risk assessment, establish a complete system of controlling interest rate risk. Regulators also want to adjust the existing regulatory system, according to actual condition more frequent use of market-oriented means to perfect the system of risk control and supervise Banks to improve the internal management. Make sure you are able to to evaluate possible 
interest rate risk, the risk control in the commercial bank within the range of affordable, avoid the resulting banking system risk [10].

\section{Conclusion}

Interest rates in the financial industry is bound to the development of the market will bring some risk for the development of commercial Banks, therefore, commercial Banks should be combined with the current situation of the development of risk assessment, and to analyze the risks, find out the solutions of the risk. In addition, should consider the differences of risk bearing, and strive to commercial Banks in interest rate market conditions to obtain good development.

\section{Acknowledgements}

For useful comments and suggestions on earlier drafts, I thank Li Ma, Jie-yu Huang. as well as workshop participants at the Economic and Management Shool of Wuhan University, the International Conferenceon Economics, Finance and Management Science in Hangzhou at 2016.

I also thank the editor, and an anonymous referee, for their professional critique and suggestions.

\section{References}

[1] Myrdal, Gunnar. "Economic Theory and Under-developed Regions," London, Duckworthand and Co, 1969, pp. 123.
[2] Song-tao zhang, "the efficiency and risk control of commercial Banks in China," China financial publishing house, 2014, pp. 113.

[3] Chu-Sheng Tai, "Time-varying market, interest rute, znd exchange rate risk premia in the commercial bank stock returns," Journal of multinational Financial. USA, vol.10, 2000 pp. 397420 .

[4] M. Eling, S. Holder, "The value of interest rate guarantees in participating life insurance contracts: status quo and alternative prodact design," Switzland, vol. 53. 2013, pp. 491-503.

[5] Yin Yong-xin, "The interest rate marketization to research on the influence of our country commercial bank risk bearing," shandong university, master's thesis in 2013, on page 11.

[6] H. Thomas. K. Murdock, and E. Joseph, "Financial restraint: toward anew paradigm," The Role of Government in East Asian Economic Development: Comparative Institutional Analysis, 1977, pp. 163-207.

[7] Yun Zhu: the empirical analysis of listed commercial Banks competitiveness of the People's Republic of China, xiamen university, Ph.D. Dissertation, 2012, pp17.

[8] A. Hoffmann, A. Löffler, "Low interest rate policy and the use of reserve requirements in emerging markets," The Quarterly Review of Economics and Finance, vol.54. 2014, pp 307-314.

[9] Jia Huang, "Based on factor analysis and empirical research on the competitiveness of commercial Banks", hunan university master degree thesis," 2012, pp 19.

[10] Lu Zhang, "Research on the competitiveness of commercial Banks based on factor analysis, shaanxi normal university," master's thesis in 2012, pp. 44. 